\title{
Restorative justice and criminal justice: limits and possibilities for Brazil and Latin America
}

\author{
Vera Regina Pereira de Andrade*
}

\begin{abstract}
This article is based on the 2017 RJIJ annual lecture and seeks to examine the development of the restorative justice movement within the judiciary in Brazil ('judicial restorative justice') in the last decade or so (2005-2017). The focus is on its relation to penal justice, listing the main possibilities and challenges in the Latin American context. The main question I wish to address is how does restorative justice, being led by the judiciary in Brazil, look like? When, where, how and under which theoretical and methodological angles is it being developed? What are the human and material resources being used? How can the relationship between restorative justice and the current Brazilian criminal justice system be understood? My hypothesis is that judicial restorative justice in Brazil is going through a process of expansion and development, framing a paradigm that is under construction and in which, despite the possibilities of challenging and transforming the current justice system, it has been nevertheless colonised by this same justice system. Therefore, restorative justice is being left to deal with low-level crimes and facing structural and conjectural limits to the concretisation of its objectives. In addition, the field in Brazil is hit by a structural lack of dialogue with other Latin American countries, which results in a mutual impoverishment of sorts, as the 'restorativism' currently experienced, hither and thither, is heated up by the intersection of emancipatory principles and values.
\end{abstract}

Keywords: Justice restorative, criminal justice, punishment, Brazil, Latin America.

* Vera Regina Pereira de Andrade is Emeritus Professor, Federal University of Santa Catarina, Florianópolis, Brazil. Contact author: vrpandrade@hotmail.com.

Acknowledgements: My gratitude to Ivo Aertsen, Estelle Zinsstag and Fernanda Fonseca Rosenblatt, for their careful revisions that followed the translation of the article by Fabricio Pontin. I am truly honoured by the triple distinction - the opportunity to deliver the Annual Lecture, the chance to write the article, and the collaboration in this memorable multi-hand work that facilitates the world's dialogue with Brazil and Latin America. 


\section{Introduction}

I want to celebrate, on behalf of the restorative movement, particularly in Brazil and Latin America, the fact that the 2017 annual lecture has taken place during the prestigious 'Sociology of Law on the Move' Conference at LaSalle University, at the heart of the state of Rio Grande do Sul, which, along with São Paulo, has led for 12 years the restorative justice movement in Brazil. This would not have been possible if it had not been for the teamwork of Ivo Aertsen, Estelle Zinsstag, Daniel Achutti and Fernanda Fonseca Rosenblatt, whom I most admirably acknowledge.

I thank you dearly for the invitation. It is a singular honour to sit on the chair for this annual lecture, a chair that imposes, immediately, a double reverence: a generational reverence, to all great names that have sat here, ${ }^{1}$ and a regional reference to all of those that, in Brazil and Latin America, have come before me, building a valuable restorative path, and that could have been here in my place. I recognise the honour bestowed upon me and the responsibility that I now bear.

I want to bring forth, in this lecture, a plural perspective. Such a plural perspective results from my own path within academia, while teaching and researching in the field of critical criminology and abolitionism, as well as within the fields of criminal policy, penal dogmatic, citizenship, democracy and human rights, and carrying out empirical work within the communities and Brazilian prisons. This is a path that has inevitably led me to restorative justice, both theoretically and empirically, with my training as a facilitator for restorative practices, the creation of the discipline of restorative justice within the Federal University of Santa Catarina, my participation in the implementation of restorative justice within the judiciary power of the State of Santa Catarina, and my coordinating role in the National Research for the National Council of Justice of the Brazilian Ministry of Justice on the topic. ${ }^{2}$

Looking back, I see a privileged trajectory, both nationally and internationally, during which I had the opportunity to break bread and exchange ideas and experiences not only with my beloved Brazilian colleagues, but also scholars in the invaluable European, Latin American and Canadian humanism circles, such as Alessandro Baratta, Boaventura de Sousa Santos, Louk Hulsman, Nils Christie, Luis Alberto Warat, Roberto Bergalli, Eugenio Raúl Zaffaroni, Lola Aniyar de Castro, Gabriel Ignacio Anitua, Rodrigo Codino, Maximo Sozzo, João Salm and Elizabeth Elliot. My standing point today, thus, draws on such exchanges, and on the

1 The previous lectures and keynotes included: 2013, in Budapest, Shadd Maruna; 2014, in San Francisco, Larry Sherman and Heather Strang; 2015, in Hong-Kong, Wong Sing Wing Dennis; and 2016, in Milan, John Braithwaite.

2 This research has been awarded a grant in a public call for applications from the National Council of Justice, in a second edition of the research programme 'Justice in Research'. It has been carried out between June 2016 and October 2017, under my coordination, and its final report is due to be published in early 2018. This research project is the basis for this article. For more information on this project, please see: www.cnj.jus.br/noticias/cnj/85599-pesquisa-identifica-justicarestaurativa-emergente-e-carregada-de-mitos (last accessed 31 January 2018). 
intersections between my theoretical and empirical experiences related both to the criminal justice system more generally and to restorative justice.

Having said all of that, in this lecture the aim is to approach the 'state of the art' of the restorative justice movement within the judiciary power in Brazil (which I would like to name 'judicial restorative justice') ${ }^{3}$ in the last decade or so (2005-2017), and its relation to the official penal justice, listing the main possibilities and challenges in the Latin American context.

The main question I wish to address is how does restorative justice, as led in (and handled by) the judiciary power in Brazil, look like? When, where, how and with which theoretical and methodological characteristics is it being developed? What are the human and material resources being used? How can the relationship between restorative justice and the current Brazilian criminal justice system be described?

As detailed in the following, the hypothesis that originated from our data is that judicial restorative justice in Brazil is going through a process of expansion and development, framing a paradigm that is under construction and in which, despite the possibilities of challenging and transforming the current justice system, it has been nevertheless colonised by this same justice system along with its deep-rooted and long-standing practices and logics. As such, restorative justice within the judiciary power in Brazil is currently limited to low-level crimes and faces structural and conjectural limits to the concretisation of its overall goals. In addition, the restorative justice field in Brazil, more generally, is hit by a structural lack of dialogue with other Latin American experiences, which results in a mutual impoverishment of sorts, as the 'restorativism' currently experienced, hither and thither, is heated up by the intersection of emancipatory principles and values.

\section{The sources and emergence of restorative justice: a paradigm under construction}

When we talk about restorative justice, we bring to the fore a hugely complex universe. The movement emerged in the 1970s as a social movement with multiple sources, increasingly marked by plurality and teleological and theoretical-practical uncertainties, which to this day set the living and ever-changing horizon of restorative justice (vitalising it, but at the same time 'dilematising' it). 'Restorativism', thus, is not a finished or monolithic practice or theory.

Incompleteness and pluralities are the main features of the movement, both regarding its empirical sources (such as its native-American, aboriginal, abolitionist, victimological and communitarian roots) as well as its theoretical and conceptual sources. These are features seen as a problem by a Western, Cartesian and positivist rationality, always keen on universalisation, uniformisations and total-

3 In the Brazilian legal context, 'judiciary power' and 'judicial' refer to the institution of the courts and the judges, at the federal, state and municipal level. It does not comprise the functions of public prosecutor or public defence. 
ising conceptualisation, which move all that is different into a field of sameness. Restorative justice's wealth, then, appears as its weakness.

Thus, the first and most reliable definition of such plurality that has taken shelter under the rubric of restorative justice is that of a movement (a movement that henceforth I will call 'restorativism'), in whose horizon experience precedes theorisation with such intensity that it is often called a practice in search of a theory (Rosenblatt, 2014 e 2016).

According to Johnstone and Van Ness (2007:5), the restorative justice movement is described as 'a global social movement with a huge internal diversity', and its broad aim is 'to transform the way contemporary societies view and respond to crime and related forms of troublesome behaviour'. Howard Zehr (2008), one of the pioneers in the movement and in the theoretical systematisation of restorative justice, has defined it as a 'change of lenses' from retributive justice. A change that allows for a new look at crime and justice, the formulation of new questions, answers and (re)actions to behaviours, which return the protagonism to those directly involved (victims, offenders and communities). Indeed, a change that has the potential to challenge the current punitive paradigm in our societies.

History as told in the literature (e.g. Braithwaite, 2002) authorises us to organise the emergence of this paradigm - which has materialised from practice to theory and developed thanks to the dialectical relationship between both spheres - into four interconnected moments:

a The 1970s, which witnessed the emergence of the restorative experience, reinforced by justice models of native populations and their relation with criminal justice;

b The 1980s, with the emergence of theorisation;

c The 1990s, as the decade of expansion; and

$\mathrm{d}$ The initial decades of the 21st century, as the revisionist and maturing period.

As detailed in the following, it was during this last period, namely from 2004 onwards, that the 'translation'4 of the restorative movement occurred in Brazil, setting it as an ever-emerging paradigm, whose protagonism has always belonged to the judicial power. Such is a personalised protagonism, as it is led by very specific people (especially judges), so much so that the continuity of restorative justice programmes in Brazil, for the most part, depends on these actors.

4 I would argue that in Brazil we have a process of construction, rather than implementation, of restorative justice practices (notwithstanding the latter being the official and sometimes replicated language). This process is better understood in the sense of 'translation' as used by Sozzo (2001), which does not exclude cultural importation, but also admits a space for creation and creativity, both socially and culturally conditioned. Translation does not imply, in this sense, a mere acritical copy, but an importation contextually framed by the translating authors. 


\section{When and who: the emergence of restorative justice in Brazil and the personalised protagonism of the judiciary power}

The legitimation crisis that affects the criminal justice system in Brazil and in Latin America, denounced in half a century of criminological critique, has been intensely worsened in the current neoliberal context of expansion of criminalisation and incarceration, which has taken the crisis to its limits. What is currently witnessed in this part of the world are the terrible and ongoing violations of human rights of suspects, prisoners under provisional detention, inmates and their relatives, ${ }^{5}$ as well as of the state agents working in the punitive system itself (as they are exposed to high levels of risk of death). And all of this without any positive result as far as the victims are concerned - in fact, the complaints of secondary victimisation have only increased. Such a scenario has evidenced the exhaustion of the current punitive model in regard to its social function, in any way that would justify the exorbitant human and financial costs of such a model, while placing the criminal justice system at the heart of the current political and judicial agendas. Such crisis, after all, will knock at the doors of the police, as well as that of the prosecutorial and judicial agencies, offering the results of years of neglect, and mirroring the agencies' institutional inefficiencies (Andrade, 2012; Andrade, 2015; Andrade, 2016; Pedra Jorge, 2005; Pedra Jorge, 2010).

Consequently, one can easily recognise a movement in Brazil (and indeed in Latin America) that stems not only from theory and academia, but also flourishes within the State and the justice system's institutions themselves, which seeks to find non-punitive alternatives to social control. Among such alternatives, not only a renewed stimulus for the application of alternative forms of punishment should be highlighted, ${ }^{6}$ but also a renewed interest of Brazil's judiciary power in restorative justice; the judiciary, whose role will be projected here far beyond a 'guest of honour' (Salm et al., 2012).

As such, the 'translation'(or construction) of restorative justice by the Brazilian judiciary power can be mapped in a continuum in which it is possible to identify two processes. First, a process self-defined as 'implementation' of restorative practices in Brazil through the launch of three pilot projects in the states of Rio Grande do Sul, São Paulo and Distrito Federal. The implementation of such pilots was supported by the Secretary of the Reform of the judiciary power (Ministry of

5 Decades of critical criminological research in this region has provided a comprehensive literature on practices of institutional violence perpetrated by the Latin American penal systems. Here we may refer to some concepts such as 'underground criminal justice system' (Aniyar de Castro, 1987), 'announced deaths' (Zaffaroni, 1993), and 'cool authoritarianism' (Zaffaroni, 2007). See also Daniel Achutti's book on restorative justice and penal abolitionism in Brazil (2014), as reviewed in this issue of The International Journal of Restorative Justice.

6 For example, the development of Brazil's 'National Policy for Alternative Punishments and Measures' (Politica Nacional de Penas e Medidas Alternativas), as well as the related creation, in 2010, of Brazil's 'National Centre for Support and Regulation of Alternative Punishments and Measures' (Central Nacional de Apoio e Acompanhamento às Penas e Medidas Alternativa). For further details, please see: www.cnj.jus.br/files/conteudo/arquivo/2016/04/c291046c303e359f32873a74b836 efcd.pdf (last accessed 31 January 2018). 
Justice) and the United Nations Development Programme (UNDP) back in $2004^{7}$ and for a period of approximately six years (2005-2010). Second, a process of 'institutionalisation' of restorative justice practices, which has as a benchmark the Resolutions n. 125/2010 and n. 225/2016, both issued by Brazil's National Council of Justice $(\mathrm{CNJ}){ }^{8}$ which grant a great deal of momentum to the restorative movement up until these days (2010-2017). ${ }^{9}$

\section{How: which restorative justice? With which theoretical and methodological frameworks, and aims?}

While 'translating' restorative justice 'to' the Brazilian context, the protagonists of this process (subjects and institutions) will be faced with all sorts of challenges that characterise the field. Namely, the plurality, the ambiguity and the need for making choices and decisions, which frame the field, both as it relates to the use of theories, methodologies and aims, as well as to all the necessary elements for the conception of restorative programmes within the limits and possibilities of the contexts wherein they are set.

In this vein, to start with, the main characteristic is that of conceptual incompleteness, which still subsists in the field. Despite its permanence, though, in the process of normative-institutionalisation, a dominant view of restorative justice has emerged in Brazil, one that is expressed in the aforementioned resolutions and in the voice of the observed restorative programmes and their actors. Within these tendencies, a common sense also emerges.

The main references quoted as a support for the programmes observed in our research, with absolute hegemony, were Howard Zehr (Changing lenses) (2008; 2012) as the main theoretical background, and Kay Pranis (Peace Circles) (2011; 2012) as the methodological frame in most of the programmes, along with Dominic Barter (Dzur, 2017) (rather than Marshall Rosenberg) in restorative circles and in non-violent communication practices. 'Culture of Peace' also appears in the background.

7 The case presented in the literature as being the first case of restorative justice in Rio Grande do Sul (or 'case-zero' as it is often referred to dates back to 13 August 2004 (Brancher \& Silva, 2008: 21).

8 Conselho Nacional de Justiça, 2010 e 2016.The Resolution n. 125, issued on 29 November 2010, and in particular in its first amendment in 2013, has set the 'National Judiciary Policy for the Adequate Treatment of Conflicts', which considers restorative justice an 'alternative to the traditional methods of conflict administration within the judiciary power'. The Resolution n. 225, then, issued on 31 May 2016, regulates a 'National Policy for Restorative Justice within the judiciary power', whereby 'courts should experiment with restorative practices according to the reality of each region or state in the country, and regardless of the reforms in lieu of the criminal and criminal procedure legislations' (CNJ, 2010). In between both Resolutions, in May 2015, the Association of Brazilian Judges (AMB) and the National Council of Justice (CNJ) launched the national campaign 'Restorative Justice in Brazil: peace asks to speak' (Justiça Restaurativa do Brasil: a paz pede a palavra). This project has as its main objectives the pacification of conflicts, the diffusion of restorative practices, and the decrease of violence.

9 Moreover, Federal Courts and Labour Courts also have their own alternative spaces for conflict resolution, and some of them adopt practices that they also name restorative justice. 
This is the triangulation that best prints a theoretical-practical face to the field of judicial restorative justice in Brazil. Other sources have also been quoted, as practical and theoretical references, but only in specific cases observed or reported to us in the frame of our project, such as John Braithwaite (and his theory of reintegrative shaming), Mark Umbreit, Andre Gomma de Azevedo and Juan Carlos Vezzulla. Nationally speaking, the most quoted references are Leoberto Brancher, Egberto Penido, Marcelo Pelizzoli, Marcelo Salmaso and, as far as training is concerned, Mônica Mumme and the practice of 'Family Constellations' are also often mentioned. Many other fields of knowledge, however, academic or empirical, compose the mosaic of restorative justice in Brazil, whether coming from the field of law, psychology or social service, or from the communities, and their concepts regularly overlap and those stemming from our 'common sense theories'.

As regards the practical modalities of restorative meetings, these are equally diverse. While some programmes conduct 'restorative reconciliation' and victimoffender mediation, other programmes use restorative circles or peace-building circles, based on non-violent communication. In any case, all practices considered, the hegemonic methodology belongs to Peace Circles, followed by Restorative Circles, Victim-Offender Mediation, Conferences, and, in an incipient level but with growing relevance (particularly in Recife), Family Constellation.

It was also observed that the focus of the programmes remains on empirical and practical matters, at the expense of theory. The priority is set at doing, implementing, applying, training, irradiating, multiplying, rather than at conceptualising and elaborating. As a rule, a deficit in the theoretical development of the field was found, which seems to relate to a deficit in more in-depth and long-lasting training. In certain cases, the mention of some restorative justice authors seemed to suffice to communicate the codes used throughout the meeting. In other cases, social workers, volunteers or public servants had started to facilitate meetings after a brief training of only a few hours, promoted by the judiciary power, which, of course, poses a great risk to all parties.

As far as human and material resources are concerned, they are diversified but, in general, very scarce, resulting in reliance on the work of volunteers.

In this vein, the cultural 'importation' (which reaffirms the 'coloniality of knowledge'), as well as the ethnocentric (particularly Euro-American) influence in the process of reception-translation of restorative justice models in Brazil, become immediately clear. And this is not about a mere reproduction, as it may appear at first glance, but rather it is about an ongoing (re)creation and, therefore, a process of 'construction', which ultimately appears as a combination of imported and national-regional influences. Such combinations allow the Brazilian restorative processes to have their own characteristics, shaped by their regional and local peculiarities. It is nevertheless the judiciary power that mostly shapes, through its ambiguities, the characteristics of a judicial restorative justice in Brazil. 


\section{Where: the geographic-institutional map of restorative justice in Brazil}

After Resolution n. 125, Courts all over Brazil started to implement Permanent Centres for Consensual Conflict Resolution ${ }^{10}$ (NUPEMECs) and Judiciary Centres for Citizenship and Conflict Resolution ${ }^{11}$ (CEJUSCs), as well as some restorative justice programmes coordinated from within these centres, which, after Resolution n. 225, went through a progressive expansion. Drawing on their headquarters in metropolitan areas, practices have expanded towards the countryside through the so-called 'irradiating poles' or 'regional units' methodologies, which involve several steps of implementation and diffusion and partnerships with local public (or state-based) and community-based services. In this vein, public policies that sometimes reach the objective of extending restorative practices to the public sector (as part of their routine) and to the cities are developed. There is a clear differentiation between regional and local development programmes (for an overview, see Table 1 in annex).

Judicial restorative justice is developed in special courts for youth and infants, and in special criminal courts for low-level crimes and violent crimes (particularly domestic abuse). Moreover, restorative justice is present at the city guard, at the state courts for sentencing and alternative measures, at elementary, medium and high schools, at football stadiums, in cities and in public services and, on all of these spaces, in constant interaction with Universities - exercised at a diversionary, pre-sentencing and post-sentencing stage.

\section{What and for whom: which behaviours and people are affected? Selective power and (re)configuration of selectivity}

Judicial restorative justice practices in Brazil are largely confined to low-level crimes. Indeed, for the most part, programmes tend to deal with the following kinds of offences: in the youth courts, ${ }^{12}$ threat of or actual bodily harm (related to family, school or neighbourhood disputes), unlawful drug use, misdemeanours and defamation; in Adult Special Criminal Courts, ${ }^{13}$ all sorts of 'low-harm crimes' (as they are called in Brazil), ${ }^{14}$ such as threat, actual bodily harm and defamation; and in Courts for Domestic Violence against Women ${ }^{15}$, misdemeanours, threat and assault.

As a rule, restorative justice programmes do not allow for trials to be suspended against the defendant, nor do they lead to an unconditional or conditional discharge, no matter whether they run within youth or adult courts. Only exceptionally, more notably in youth courts, the use of restorative justice may suspend

10 Translation for: Núcleos Permanentes de Métodos Consensuais de Solução de Conflitos (NUPEMECs).

11 Translation for: Centros Judiciários de Solução de Conflitos e Cidadania (CEJUSCs).

12 Translation for: Juizados da Infância e da Juventude.

13 Translation for: Juizados Especiais Criminais.

14 Translation for: crimes de menor potencial ofensivo.

15 Translation for: Juizados de Violência Doméstica e Familiar contra a Mulher. 
trial proceedings. Moreover, in youth courts as well, the use of restorative justice may also occur after penalties are remitted or criminal cases are archived or discharged, as a means of enhancing the existing (psychological and other) support services offered to the young offender and his family. When the restorative justice process runs in parallel to the criminal justice process, the final decision on the case belongs to the judge, which compromises the essence of restorative justice as a process whereby the affected parties should be empowered to 'own' their conflict (Christie, 1977), deciding, thus, for themselves.

Our empirical data also suggest that, because restorative justice programmes tend to run within special, limited-jurisdiction criminal courts (as a rule, focused on low-level crime), the 'clientele' of such programmes in Brazil is the same population that tends to knock on the doors of these specialised courts: groups within the lower social spectrum, mostly males within youth courts and special criminal courts, and female victims in case of domestic violence.

It should be highlighted, however, that our research has shown low presenceadherence of victims (except in cases of domestic violence). The evaluation of the pilot areas (ILANUD, 2006), conducted over 10 years ago, has also shown that victim participation rates are low, which suggests a continuing and permanent stain on the structure of projects, one that compromises the restorative meetings themselves.

The counterpart of this finding is the observation that the presence-adherence of offenders, both youth and adult offenders and at any stage of the criminal proceedings, is much higher than the participation of victims. In this context, programmes tend to focus on offenders, and this seems to be for two main reasons: either because restorative justice practices are used after an offender is sentenced in court (i.e. restorative justice at post-sentencing level, as part of the offender's punishment), or during the trial proceedings when there is housearrest or electronic surveillance, but in all these cases focused on the offender; or for a principled reason - restorative justice programmes in Brazil seem to have the responsibilisation of the offender (with a preventive and peace-making aim) as the central principle at play (as opposed to the reparation of harm caused to victims and communities, for example).

One should keep in mind, however, that restorative justice's compass in Brazil is the youth justice, and its clientele is (those who are generally called) 'boys'. That is, notwithstanding the violent process of stigmatisation and tendency of increasingly premature ${ }^{16}$ criminalisation of such boys, they are also perceived as in need of protection and care, or, simply, to be considered as victims.

Another key finding is that the complete restorative cycle (pre-circle, circle and post-circle) is usually not possible, with interviewees commonly reporting that 'post-circles' are not being held.

All in all, restorative justice programmes in Brazil reproduce the structural logic of the inner workings of the justice systems they depend on and conse-

16 Please note the Brazilian movement for the reduction of criminal responsibility age, materialised in several Bills which are under analysis in the Brazilian Congress, and in several sectors of society, both in terms of formal (justice system) and informal (mainstream media) social control. 
quently reconfigure the selectivity of the system as their own, as the selection of behaviours and people that are engaged in restorative practices depends not only on normative guidelines, but especially on the judge (usually in the first hearing), the prosecutors, the public defenders, the police or the parties themselves (when possible) referring the cases to a given restorative justice programme. On the other hand, a refusal by the prosecutor in acknowledging the referral may hinder any attempt at making restorative justice a concrete possibility.

At the output of restorative justice practices, the protagonist is again the judge, since, as it is often the case, referring the parties to a restorative justice programme does not allow for trials to be suspended against the defendant, and, should there be any restorative agreement, homologation by the judge is necessary (so to say that its terms might or might not come to fruition), who may also decide to impose alternative punishments. ${ }^{17}$ That is, even when a restorative encounter (circles or mediation) is possible between the parties (offender-victimcommunity), and space is made for them to be heard, they are not empowered to voice what they think would be fair. Indeed, the judge remains with the last word regarding the validity and normative efficiency of restorative justice processes.

\section{Theoretical-methodological and normative frameworks: the practices in relation to Howard Zehr's theory}

Our research used as basic theoretical framework, also in regard to the concept of restorative justice, the works of Howard Zehr, both because of his standing as a global reference in the field and because he was hypothetically believed to be the dominant point of view in Brazil.

Such hypothesis has proven to be the case: Howard Zehr is indeed the most commonly mentioned author by those working with judicial restorative justice in Brazil. However, despite Howard Zehr's standing as the most often-mentioned reference, on the ground, restorative practices have little to do with Zehr's concept of restorative justice, at times failing to even partially fulfil their constitutive elements, specifically those regarding the demand for the participation of 'victims' in the restorative procedures, or to the reparation of harm, or to the principles of participation and empowerment.

Indeed, when restorative justice is placed as a self-composed method, not only of conflict resolution, but also of preventing further conflicts, and, in this sense, as a method which is 'alternative' to punishment, those concepts better suited for a punitive approach to justice are inserted at the heart and objectives of restorative justice programmes in a direct or indirect way, such as special prevention (oriented to resocialisation and reintegration), which is a declared function of the prison sentence. And this has not only been observed in restorative programmes implemented at post-sentencing stages (which are openly focused on the offender and on realising special prevention), but in restorative programmes

17 There is no regulation in the law or in Resolution 225 about the criteria to refer cases to RJ or on the follow-up of an agreement by the judge; those are all discretionary decisions made by the judge or other authorities. 
placed at any stage. As such, punitivism appears anew through the performance and discourses of restorativism.

At the same time, terms such as 'crime' are apparently being replaced by others such as 'conflict' and 'violence', although restorative justice practitioners commonly lend the same old stereotyped and stigmatising meanings to these new labels. On the other hand, we have observed that there are other projects led by the judiciary power (or by the Secretary of Education) that meet all the characteristics of a so-called restorative process, even if we take Howard Zehr as a leading clue, notwithstanding their preventive/pre-processual nature and the fact that they have been implemented by other public services (with support by the judiciary).

All things considered, it was found that the theoretical framework provided by Howard Zehr seems too limited to give full account of the complexity of the projects at play in Brazil. In this context, our efforts to broaden the theoretical framework upon which our research was based should be highlighted. Drawing on a tripartite conception of restorative justice as a model aimed at 'encounter', 'reparation of harm' and 'transformation', we may affirm that: (a) the 'encounter' is a generalised objective sought by all observed programmes, but that often fails to occur for a myriad of reasons, especially the lack of adherence by victims; (b) whenever 'encounter' does occur, it is within the spaces of the justice system itself, often at courts, which may well be considered the least appropriate place; (c) harm reparations is a residual, rather than central, objective in all observed programmes; (d) the transformation of people (subjectivity) or of their (violent) form of communication and relationship with others is generally present, at times as an expressed aim, and at other times as an unspoken aim, and it acquires different shapes in different programmes.

In any case, because the aim is the 'resolution' of the conflict, conflicts appear on the ground as something that must be 'resolved', 'solved', 'eliminated'. What then seems to unfold is that the space made for restorative justice practices ends up being used, indirectly, as a space to try out social policies that may provide needs and even human rights that have been for so long denied by the families and/or the State to these 'boys'. In other words, what seems to happen is that judicial restorative justice attempts to take this empty space left by the Executive Power (Government), and compensate it within the limits of its possibilities, as a Judicial Restorative State.

\section{Common sense and restorative mythologies in Brazil: the epistemological obstacle and the need for overcoming mythologies}

During this 'construction' process, what can be observed in Brazil is the consolidation of a certain common sense, based on a set of representations that seem to fit a mythology of restorative justice in Brazil.

Such mythology, reproduced by critics of restorative justice more often than by restorativists themselves, seems to operate as an epistemological and political obstacle to restorative justice's emancipatory potential. Hence the need to over- 
come the myths of celerity, instant training/capacitation, conflict resolution, lowlevel criminality and the alternative method for conflict resolution.

\subsection{The myth of celerity}

A dominant view in Brazil holds that restorative justice can be used to unburden the judiciary, inasmuch as it is an informal type of justice, simpler and faster. No claim could be as superficial as that if we consider our findings on the ground. Restorative justice has its own time, its own temporality and may not be run over by productivist demands, and any such conception of restorative justice is stillborn. This is not 'fast food', to quote judge Egberto Penido (2016: 193).

\subsection{The myth of instant training/capacitation}

The same technical conception that ignores the guiding principles and values within restorative justice ignores the subject, believing that it is enough to provide a single and instant stance of training, on a single methodology, and trusting that training sessions delivered in lightning speed will be able to capacitate individuals. The adequate training for a demanding type of justice is continuous training, supported by ongoing processes of self-evaluation and monitoring, along with exchanges and learning experiences that are not only vertical but horizontal and transversal.

\subsection{The myth of low-level criminality or the impossibility of applying restorative justice in cases of domestic violence}

The mainstream view is that restorative justice only fits low-level or low-harm crimes and misdemeanours. Such views gain strength in Brazil particularly within the context of the special criminal courts. There is a naturalisation and naturalised reproduction of this myth, even though there are restorative justice programmes in Brazil operating within the remit of more serious crimes, such as with domestic violence, although only exceptionally and particularly at the postsentencing stage. This, for example, is happening, with relative success, within the special Courts for Domestic Violence in the cities of Novo Hamburgo and Porto Alegre. When asking about such matter, responses were quite diverse from judges who claim they 'were not ready to work with more serious or highlevel crimes' or that 'they had not reached abolitionism yet', up to 'there is no way to apply techniques of mediation in matters of gender, where there are power imbalances at play' and, finally, judges who defended, resolutely, the possibility of applying restorative justice in any case.

\subsection{The myth of restorative justice as a method of conflict 'resolution': a myth that stems from the 'avoidance' of criminality, reoffending and victimisation}

The previous myths seem to derive, in great measure, from the central myth: the one that sets restorative justice as a consensual 'method' of conflict 'resolution'. There is a widespread understanding that restorative justice is a method that offers a very specific merchandise, a pacifying product. What then follows is the myth that, once conflict is 'resolved', one is avoiding 'criminality', 'reoffending' and 'victimisation'. Restorative justice may legitimately include such a resolution- 
oriented and preventive dimension, but it cannot (or should not) be reduced to this dimension, in fact, such reduction is a 'de-potentialisation' of its meaningful core, which sets a new ideal of justice integrated by values, principles and techniques.

\subsection{The myth of 'alternativity': an alternative to what?}

Despite the arguments presented here, the view of restorative justice as an alternative justice, or an alternative method to criminal justice, is still the dominant one. One should bear in mind, though, that the selectivity operated by restorative justice practices in Brazil, as a rule, does not even allow for their application within the remit of the adult courts. In fact, in the few cases where this is possible, restorative justice is only used for low-level crimes (within low or medium social stratum) or domestic violence, and does not allow for trials to be suspended against the defendant. Even within youth courts, which indeed constitute restorative justice's broader horizon of projection in Brazil, procedures run in parallel to the regular or traditional proceedings. This is to say that restorative justice may only have a small impact on the reduction of punishment of young offenders in Brazil, but it certainly does not configure an alternative to any kind of justice at all.

\section{What is the position of restorative justice in relation to the criminal and youth justice systems?}

What kind of relationship currently exists between both types of justice? That is, between restorative justice and the dominant model of criminal justice and youth justice? And what sort of social control has been (or is being) produced?

Judicial restorative justice is an 'emerging paradigm' in its relation to the 'dominant paradigm' in operation within the criminal and youth justice systems. And as such, it is inserted in an interval of contradiction and ambiguity, 'between' the symptoms of a (legitimation) crisis that affects the old punitivism and the tension, produced within this same punitivism and by the new elements of an emerging paradigm.

The dominant paradigm, in its turn, in a hegemonic fashion, struggles to block the new meanings and innovations, reacting, resisting, creating obstacles and co-opting (or integrating elements of the new paradigm), in order to avoid letting go of the control and dominium imposed by its current situation. It was such the ambiguity and tension that emerged from the universe observed in the field and from the voices heard in the theory (literature) and the empirical component of our research (the restorative experiences).

The leading actors and those working with restorative justice more generally (judges, justices, prosecutors, state defenders, policemen and women, psychologists, social workers, and, remarkably, volunteers) have had to deal with a doublepressure: on the one hand, they must deal with the internal resistance of those traditionally operating the justice system, a resistance that is often fed by the aforementioned myths; and, on the other hand, it must deal with an external 
pressure (suspicions and uncertainties that arise from the parties themselves, the communities, the political system and other programmes), which may potentialize a tendency to trap restorative justice in its trusting circuit. At the same time, there is a need for a huge investment in the unification and canalisation of struggles towards opening physical spaces, acquiring human resources, creating and sustaining programmes, which demand collective intelligence and energy to deal with violent power structures. And in spite of all this, it should be noted, the restorative network continues to grow and gain strength.

As an emerging paradigm, and in relation to the criminal and youth justice systems, restorative justice is in a position of paradigmatic dependence and relative autonomy. It is being built (implemented and institutionalised) from within, placed on the margins of the dominant justice system and it has remained dependent on it for its workings, on an institutional as well as epistemological level, and in terms of human and material resources.

Restorative justice is dependent on official justice, working as its appendix and dealing with its residual content (low-harm or low-level criminality). Indeed, at present, there are no juridical or even ideological conditions for the restorative movement to claim the central content of criminal or youth justice, whose basis is the positivistic concept of crime and punishment. Before anything else, we must realise that the numbers related to restorative justice within the regular justice system is qualitatively and quantitatively inexpressive. There is a legal limit to its quantitative expansion within criminal justice, and qualitative limits to its paradigmatic consolidations such as ideological resistance, which comes from the strengthened hegemony of the punitive paradigm.

Restorative justice nevertheless presents a relative autonomy in relation to the current justice system, which helps us explain, for example, regional and local differentiations among programmes. It is in this autonomisation that we must place our bets in.

Alas, there are strong signs that rather than producing tension within the state system of justice in order to insert its constitutive elements (participation, empowerment of the parts, alterity, harm reparation, violence reduction and so on), thus impacting and changing the hegemonic system itself, it is the punitivistic justice, with its own arsenal, which is colonising restorative justice in Brazil, taking advantage of the coexistence of the models to hypothetically expand its social control. At the end of the day, it is the State that seems to be expanding under the guise of the society-community.

The judicial restorative justice movement now starts to take shape, with clear regional and local diversities. Nevertheless, it is, for the most part, the shape of the Brazilian judiciary power, which models, within its ambiguities, the face of a possible judicial restorative justice. 


\section{The silence regarding Latin America in the narratives of restorative justice: a dialogue rich in possibilities}

Finally, we must stress some silences or absences. And among those, perhaps the most evident is the silence regarding Latin America in the narratives dealing with the origins of restorative justice (as well as in other dialogues about restorative justice). It is as if nothing is going on outside the Anglo-Saxon America, or, if there is a history for the Latin American region, this history is not told, neither by the North nor by the South itself (particularly Brazil).

In this research project, one of the hypotheses confirmed is that there has been a silencing of such voices and history, ${ }^{18}$ for a lot has been going on outside the Anglo-Saxon scene in the field of restorative justice, notwithstanding the fact that the Latin American countries that have taken the 'restorative' rubric forward have done so in the context of an Anglo-Saxon influence. Without demeaning other countries, this seems to be precisely the case in Brazil (where at first the term justiça restauradora or 'restoring justice' was used), Argentina (where mediation is prominent) and Chile.

At the same time, while the Global North develops its own history of restorative justice, Mexico, Venezuela, Colombia, Bolivia, Peru, among others, also go through a rich process as they struggle for the development of a 'communitarian justice' (this is the nomenclature most often adopted); above all among their native populations and farmers, which reclaim their autonomic justice system that was destroyed through the violence of a secular, state-run, monist, bourgeois and white justice. They translate libertarian struggles against secular supremacy, reaffirming values of identity and reconnection, of community empowerment and participation, of pluralism and interculturality. Moreover, such struggles have obtained constitutional recognition in Colombia, Bolivia and Peru, ${ }^{19}$ signalling towards a new, Latin American constitutional pluralism. ${ }^{20}$

Such experiences are not normally placed within restorative justice's cultural matrix, notwithstanding the fact that they share some of the same agenda and values of the restorative movement, such as respect, alterity, inclusion, reconnection and an entire history of discussions on what justice means in the subcontinent, as it relates to the formal State justice system. There is something missing in the field, of potential North-South dialogue, and of learning opportunities that go 'South-North' as well as 'South-South', regarding matters of justice.

From the Global North, those of us in Brazil (and in the Global South more generally) could learn that the restorative debate has taught to value ancestrality,

18 A dominant, but not monolithic, silencing, as there are obvious exceptions, manifested in efforts of visibility that aim at bringing Latinity forward. Note, particularly, the works of Wolkmer (2012), Lixa ( 2013) and Leal (2011).

19 It is a hallmark for the discussion of judicial pluralism, and Latin American critical and decolonisation theories that the debate about communitarian justice, native justice and neo-constitutionalism have taken central stage. For more on this, see Leal (2018) and Leal and Machado (2011).

20 Please note the Colombian Constitution of 1991 (Arts. 246 and 247), the Peruvian Constitution of 1993 (Art. 149), the Bolivian Constitution of 2007 (Art. 1 and Chap. 4) and the 1992 Protection Act for Peruvian Agrarian Communities (Act 24.656, Art. 5). 
bringing it forward and making it visible. ${ }^{21}$ And from the Global South, those of us in Brazil could learn how to value and make our common history more visible, connecting ours with the history of the Americas that went through the Spanish colonisation, which often do not dialogue with Brazil - in fact, Brazil often takes an imperial position regarding these countries. While Brazil or, indeed, the triangulation between Brazil, Argentina and Chile, is producing a restorative debate that is framed by the Anglo-Saxon cultural import, other countries within the Spanish-speaking Latin America are leveraging a debate on community justice that goes beyond the boundaries of the community as a simple supporting actor in the practices within the restorative triad. Rather, this debate has brought forth the community struggle to reclaim its ancestrality and the need for it to be recognised and included in the society and the State. Both (restorative and communitarian) movements are quite important, but placing both in dialogue would make each of them epistemologically and politically stronger.

\section{Final remarks}

Restorative justice has made significant progress in Brazil, gaining important judicial and non-judicial spaces, accumulating knowledge and experience in the youth and adult (criminal) justice systems, while building restorative communities of sensible qualification and humanist intelligence, an intelligence that Pelizzoli $(2008 ; 2016)$ has called 'collective intelligence'. As such, restorative justice has opened a field of new possibilities to the history of the punitive saga. Structural and contextual limits and challenges to the consolidation of restorative justice as a new paradigm of justice in Brazil have been nevertheless brought forth.

As for 'judicial restorative justice', it is a field under construction, open and marked by ambiguity. On the one hand, it is essential to recognise the advances and achievements accumulated in terms of experience, knowledge, production of pacts and norms, communities and results (although not yet duly quantified) and to conclude that judicial restorative justice, despite its youth, has a history to tell. At the same time, it is essential to recognise the quantitative and qualitative limits that have selectively conditioned its development. It is not possible to enter the field of judicial restorative justice in Brazil with the adult-centric look, because, in this field, the flagship is youth justice. And much of what appears to be a forerunner in the field is, in fact, conditioned by it - so a 'native' challenge is to have this premise on the horizon.

Advancing with many potentialities, challenged by innumerable limits, judicial restorative justice has been built as a multi-effort movement, including personal, interinstitutional and interdisciplinary efforts. The face of this movement has been shaped by practices, conceptions, norms and policies, which at times brings new approaches to justice, and at times seem to be stuck in the old ways, such as the force of the punitive paradigm and the mythologies of common sense. 
Its potentialities, thus, stem from this consolidated accumulation, which is the basis for its future journey, associated with its ability to overcome obstacles, through a permanent process of evaluation, in which the university and public research in general have an important role to play. The concern of the National Council of Justice (CNJ) is not other, and is one that motivated this research project (among others), based on Chapter VII of the aforementioned Resolution n. $225 / 2016$.

As for the limits and challenges to the consolidation of restorative justice as a new paradigm of justice in Brazil, these were mapped and categorised into four closely related dimensions: legal/technical, operational, democratic, epistemological/ ideological.

The first one is of a legal nature. Considering that restorative justice has developed within the justice system, it is dependent on the current legislation, which grants the monopoly of the public action to the public prosecutor's office through the 'principle of mandatory criminal prosecution' (Article 129, item I, of the Brazilian Constitution), conditioning the spaces in which restorative processes may unfold. Such spaces are found in special courts that have created exception to this principle (special criminal courts and youth courts) or that, in spite of maintaining it, have allowed for the use of practices that are different from the traditional punitive ones (Courts for Domestic Violence against Women). This holds restorative justice initiatives back, mostly within the remit of low-level crimes, and to overcome such legal limits, we need structural reforms at a constitutional and an infra-constitutional level.

The second limit is at the operational level of resources and sustainability of the restorative justice programmes. Notwithstanding the support by the courts of justice with regard to training, the programmes have been developed without the allocation of specific and sufficient human and material resources, and their staff have generally exercised functions in conjunction with their regular duties as public servants of the (traditional) justice system, with the consequent formation of a body of volunteers working in parallel to the civil service. The same conditions affect the judges and justices, who led the programmes and have become their true protagonists. Moreover, a strong personalisation marks both the protagonists and the practitioners in general, who push the programmes forward due to their own idealism and personal commitment. The consequence of this dual situation (resource deficit + personalised protagonism) is that the sustainability of the programmes is still very weak in Brazil.

The third limit is of a democratic nature. It concerns the difficulties of participation of victims, even victims of domestic violence, in restorative practices, to the detriment of the ideals of encounter and dialogue, which constitute the centre of an authentic restorative paradigm. A difficulty was also observed in the completion of the complete restorative cycle, as the last step, the post-circle, is usually hampered.

Structurally speaking, it has been observed that, despite the judiciary's efforts to consolidate a horizontal and democratised restorative justice, open to participation by the parties and the community, judicial restorative justice initiatives in Brazil are marked by a very institutionalised and vertical identity, which ends up 
reinforcing the (selective) power of judges and, secondarily, prosecutors, police officers and public defenders. What is more, in view of the difficulties to promote meetings between the affected parties, these professionals end up upholding the power of intervention over offenders, which often assumes the character of a normalising-moralising power, particularly within the remit of the youth justice system - all at the expense of transferring discretion to the parties.

The fourth limit is epistemological, cultural and ideological. It refers to the resistance offered by the criminal justice professionals themselves to the transformations invoked within the framework of the emerging paradigm, as some seek the perpetuation of the representations that are typical of the punitive paradigm, and, in general, of the mythologies that obstruct an enlarged and humanistically qualified view of restorative justice. Of particular note is the confinement of restorative justice to the so-called crimes, infractions, violence, conflicts or (problematic) situations considered to be 'less serious' or with 'less offensive potential'. Such a confinement both feeds the parallelism of restorative justice in relation to the 'official' justice, and places an obstacle to address structural issues, such as the criminalisation of poverty and drugs, which is responsible for the mass incarceration and genocide of poor youths. While these structural issues are ignored, there will be no possible 'pacification' in the Brazilian civil war enforced by the criminal justice system and the public security apparatus, which is, in fact, a reflection of the problems of class, race and gender in Brazil.

In short, a model of restorative justice focused on the responsibility of the offender, on the prevention and pacification of conflicts, and, finally, on the transformation of subjectivities and intersubjective relations, with a very limited scope, is being designed in Brazil. A model that differs from both the Euro-American matrix of the Global North, focused on the participation of the victims and on the reparation of harms, as a priority, as well as from the Latin American matrixes of the peripheral countries, focused on autonomous communitarianism, whose construction can only be understood contextually - that is, in light of the concrete Brazilian and regional context in which these restorative justice programmes are founded and fill their history, and especially in the light of judiciary power that guides them or 'drives' them. In this respect, the present research has also raised a set of hypotheses, whose approach, however, goes beyond the scope of this lecture, demanding a specific space.

The state of the art of restorative justice, thus, within Brazil's judiciary, cannot be evaluated by reference to the abstract comparison of our reality with experiences and theorisations produced in other realities. Rather, it needs to be evaluated contextually, that is, from its insertion in the concrete conditions in which it happens, being also influenced by theories and practices of other contexts, and the way these are 'translated' (Sozzo, 2001).

As a goal, a qualitatively humanistic restorative justice is proposed, whose main challenges today are: (a) to overcome the elements of the punitive paradigm in its elaboration and to impact such elements in their destination and results, without it being structured instrumentally, but as a new paradigm of experiential and democratic justice; (b) establish itself with autonomy before the punitive paradigm and the legal paradigm itself; (c) move towards the permanent 'horizon- 
talisation' of its subjective base, returning the protagonism of justice to the affected parties (individuals and community); (d) move towards a permanent extension of its behavioural base, breaking with the stigmatising dichotomies between behaviours that can and cannot be covered by restorative justice initiatives, to harbour any behaviour, as long as the parties voluntarily agree to it; (e) therefore move towards democratisation and expansion of its political base, effectively distributing the power 'to do' justice.

As far as the potentialities are concerned, the signs of satisfaction of the parties and the strength of the practitioners are particularly noteworthy. Although this was not a research focused on listening to the parties, all those who we had the opportunity to interview, reported great satisfaction with the 'experience' of restorative justice, in several senses, based on which a specific research with the parties is suggested for the future.

As for the communities of protagonists and restorative justice practitioners, the field has shown itself to be vigorous, with an extraordinary commitment and humanistic vocation, and it must be noted, with a strong participation of women and significant feminine dimension.

We have observed the daily life of individual, collective and institutional subjects who spend a gigantic daily energy, among their daily obstacles and resistances, to carry out the utopia of a new justice, by and for human beings. Subjects who, for the most part, are critically aware of the problems of restorative justice, but who are much more aware of punitive barbarism and who understand how important it is to withdraw situations from that jurisdiction.

In the end, despite all the highlighted difficulties, testimonies and moving records of extremely positive experiences in the lives of people, communities, practitioners and institutions, have been collected from the field, which reaffirm the humanist advances and potentialities of the restorative path.

If restorativeness is, as confirmed in the research, a 'path that is done while walking', incomplete, unfinished, always seeking qualification (and the demand for further opportunities of qualification is persistent in the field), the genuine restorative utopia for Brazilianness (and not just for Brazil) is the permanent effort to make the tides turn (always tending towards institutional 'functionalisation') for a humanistic qualification. Indeed, the only qualification that can lead us to a structurally libertarian justice, capable of blocking the course of the punitive river and its structural dehumanisation. In this sense, the restorative path appears as an available and irreversible path to be appropriated by people who are members of communities and institutions, among which the judiciary has played a fundamental historical role for the democratic transformation of justice in Brazil.

\section{References}

Achutti, D. (2014). Justica restaurativa e abolicionismo penal: contribuicoes para um novo modelo de adminstração de conflitos no Brasil. São Paulo: Saraiva. 
Andrade, V.R.P. (2012). Pelas mãos da criminologia: o controle penal para além da (des)ilusão. Rio de Janeiro: Revan.

Andrade, V.R.P. (2015). A ilusão de segurança jurídica: do controle da violência à violência do controle penal. Porto Alegre: Livraria do Advogado.

Andrade, V.R.P. (2016). Sistema penal máximo x cidadania mínima: códigos da violência na era da globalização. Porto Alegre: Livraria/Editora do Advogado.

Aniyar de Castro, L. (1987). Criminologia de la liberación. Maracaibo: Universidad de Zulia.

Braithwaite, J. (2002). Restorative justice and responsive regulation. New York: Oxford University Press.

Brancher, L. \& Silva, S. (eds.). (2008). Instituindo práticas restaurativas, semeando justiça e pacificando violências: três anos de experiência da justiça restaurativa na capital gaúcha. Porto Alegre: Nova Prova.

Conselho Nacional de Justiça (CNJ). (2010). Resolução no 125 de 29 de novembro de 2010. Retrieved from: www.cnj.jus.br/busca-atos-adm?documento=2579 (last accessed 24 September 2017).

Conselho Nacional de Justiça (CNJ). (2016). Resolução no 225 de 31 de maio de 2016. Retrieved from: www.cnj.jus.br/images/atos_normativos/resolucao/resolucao_225_ 31052016_02062016161414.pdf (last accessed 24 September 2017).

Christie, N. (1977). Conflict as property. The British Journal of Criminology, 17(1), 1-15.

Dzur, A. (2017). Conversations on restorative justice: a talk with Dominic Barter. Restorative Justice: An International Journal, 5(1), 116-132.

United Nations Latin American Institute for the Prevention of Crime and the Treatment of Offenders (ILANUD). (2006). Sistematização e Avaliação de Experiências de Justiça Restaurativa. Unpublished Report.

Johnstone, G. \& Van Ness, D. (2007). The meaning of restorative justice. In G. Johnstone and D. Van Ness (eds.), Handbook of restorative justice (pp. 5-23). Cullompton: Willan Publishing.

Leal, C.B. (2011). Justiça restaurativa: o crepúsculo de uma era. Curitiba: Juruá.

Leal, J. (2018). As práticas de juridicidade alternativa na América Latina: entre o reformismo e o impulso desestruturador - um alerta a partir de Stanley Cohen. Revista Brasileira de Politica Publicas. [Forthcoming]

Leal, J. \& Machado, L. (2011). Acesso à justiça: perspectivas críticas a partir da justiça comunitária andina. Revista de Direitos e Garantias Fundamentais, 9, 37-76.

Lixa, I.M., Veras Neto, F.Q. \& Wolkmer, A.C. (2013). Pluralismo jurídico: os novos caminhos da contemporaneidade. São Paulo: Saraiva.

Pallamolla, R.P. (2017). A Construção da Justiça Restaurativa no Brasil e o Protagonismo do Poder Judiciário: permanências e inovações no campo da administração de conflitos (Doctoral Thesis). Universidade Católica do Rio Grande do Sul, Porto Alegre, Brazil.

Pedra Jorge, A. (2005). Em busca da satisfação dos interesses da vítima penal. Rio de Janeiro: Lumen Juris.

Pedra Jorge, A. (2010). Criminal justice, victim support centers, and the emotional well-being of crime victims (Doctoral Thesis). Université de Lausanne, École de Sciences Criminelles, Institut de Criminologie et de Droit Pénal, Switzerland.

Pelizzoli, M.L. (ed.). (2008). Cultura da paz: educação do novo tempo. Recife: UFPE.

Pelizzoli, M.L. (2016). Cultura de Paz Restaurativa. In M. Pelizzoli (ed.), Justiça restaurativa: caminhos da pacificação social (pp. 13-45). Caxias do Sul: Educs / Recife: UFPE.

Penido, E. (2016). Formações: um processo contínuo de investigação. In F.B. Cruz (ed.), Justiça restaurativa: horizontes a partir da Resolução CNJ 225 (pp. 193-197). Brasília: CNJ. 
Pranis, K. (2011). Guia do facilitador. Retrieved from: http://justica21.web1119.kinghost. net/arquivos/guiapraticakaypranis2011.pdf (last accessed 30 August 2016).

Pranis, K. (2012). Processos circulares. São Paulo: Palas Athenas.

Rosenblatt, F.F. (2014). Em busca das respostas perdidas: uma perspectiva crítica sobre a justiça restaurativa. In G.M. Carvalho, F.A.F.N. Deodato \& F. Araujo Neto (eds.), Criminologias e política criminal II (pp. 443-465). João Pessoa: CONPEDI.

Rosenblatt, F.F. (2016). Pesquisa em justiça restaurativa. In M. Pelizzoli (ed.), Justiça restaurativa: caminhos da pacificação social (pp. 113-129). Caxias do Sul: Educs/Recife: UFPE.

Salm, J. \& Leal, J. da S. (2012). A justiça restaurativa: multidimensionalidade humana e seu convidado de honra. Sequência, 64, 195-226.

Sozzo, M. (2001). 'Traduttore traditore': importación cultural, traducción e historia del presente de la criminología en America Latina. Cuadernos de Doctrina y Jurisprudencia Penal, 7(13), 354-431.

Wolkmer, A.C. (2012). Pluralismo jurídico: fundamentos deuma nova cultura no direito. São Paulo: Alfa-Ômega.

Zaffaroni, R. (1993). Muertes anunciadas. Bogotá: Temis/Instituto Interamericano de Direitos Humanos.

Zaffaroni, R. (2007). O inimigo no direito penal. Rio de Janeiro: Revan.

Zehr, H. (2008). Trocando as lentes: um novo foco sobre o crime e a justiça restaurativa. São Paulo: Palas Athena.

Zehr, H. (2012). Justiça restaurativa. São Paulo: Palas Athena.

\section{Annex}

Table 1 Map of restorative justice practices within the Brazilian judiciary power.

\section{CENTRE-WEST REGION}

State/Cities

DISTRITO FEDERAL Núcleo Permanente de Métodos Consensuais de Solução de Conflitos (NUPECON)

GOIÁS

MATO GROSSO

Núcleo de Práticas Restaurativas

NUPEMEC

MATO GROSSO DO SUL

\section{Court (judicial competence)}

Juizados Especiais de Processual (pre-senCompetência Geral do tencing stage)

Juizado da Infância e da Processual (pre-senJuventude de Goiânia tencing stage) da Infância e Juventude tencing stage)

Vara da Infância e Juventude de Campo Grande (youth offendmento da Justiça Restaurativa (PAJUR)
Fórum do Núcleo Bandeirante (low-level crimes) (youth offending)

2a Vara Especializada Processual (pre-sende Cuiabá (youth offending)

Processual (pre-sen-

\section{Criminal proceed- ings stage}

tencing stage)

ing) 


\section{NORTHEAST REGION}

State/Cities

BAHIA

MARANHÃO

PIAUÍ

SERGIPE

\section{Coordination}

Núcleo Permanente de Métodos Consensuais de Solução de Conflitos (NUPEMEC) / Núcleo de tiça Restaurativa nil Restaurativa / Projeto RestaurAÇÃO

PERNAMBUCO

\section{Court (judicial competence)} tema dos Juizados level crime) Juventude de São José offending)
Núcleo de Justiça Juve- $2^{\text {a }}$ Vara da Infância e
Coordenação da Infância e da Juventude / Central de Práticas Restaurativas 5a e 6a Varas do SisEspeciais Criminais do Largo do Tanque (low-

\section{Juizado da Infância e da} Juventude (youth offending) / Juizado do Torcedor (football related violence) / Presídios (prisons) / Sistema Socioeducativo (young offender institutions)

Núcleo de Justiça Juve- $2^{\mathrm{a}}$ Vara da Infância e nil Restaurativa da Juventude de Teresina (youth offending)

Processual (pre-sentencing stage)

\section{Criminal proceed- ings stage}

Processual (pre-sentencing stage)

Pre-processual, processual and post-processual Vara da Infância e da Processual (pre-sen-

Coordenadoria da Infância e Juventude / Juventude de Aracaju e tencing stage) Núcleo de Práticas de Canindé (youth Restaurativas offending)

\section{NORTHERN REGION}

\section{State/Cities \\ Coordination \\ Court (judicial competence)}

ACRE

AMAPÁ

PARÁ
Núcleo da Justiça Restaurativa

Comarca de Santana

Coordenadoria Estadual da Infância e da Juventude $1^{\circ}$ Vara da Infância e Juventude de Rio Branco (youth offending)

Juizado de Violência Doméstica e Familiar contra a Mulher (domestic violence)

Vara de Infância e Juventude de Belém, de Santarém, de Altamira, de Paragominas e de Abaetetuba (youth offending) / $3^{\mathrm{a}}$ Vara de Violência Doméstica e Familiar contra a Mulher (domestic violence)

\section{Criminal proceed- ings stage}

Pre-processual (in schools)

Processual (pre-sentencing stage)

Processual (pre-sentencing stage) 
RONDÔNIA

TOCANTINS

SOUTHEAST REGION

State/Cities

MINAS GERAIS

SÃO PAULO

$I^{\circ}$ Juizado da Infância e $I^{\circ}$ Juizado da Infância e Pre-processual (in da Juventude da Juventude de Porto schools) Velho (youth offending)

Centro de Execuções de Penas e Medidas Alternativas (CEPEMA) Projeto Conciliação,

Coordenadoria da Infância e da Juventude

\section{SOUTHERN REGION}

State/Cities

PARANÁ

\section{Coordination}

Núcleo Permanente de Métodos Consensuais de Solução de Conflitos (NUPEMEC) $2^{\mathrm{a}}$ Vara Criminal e de Execuções Penais de Araguaína (court overseeing the punishment of adults already sentenced by a criminal court)

\section{Court (judicial competence)}

\section{Criminal proceed- ings stage}

Vara da Infância e Juventude da Capital (youth offending) / Juizado Especial Criminal da Capital (low-level crimes) Municipalities of Guar- Pre-processual (in ulhos, São Paulo, San- schools)

tos, Tatuí, Itajobi,

Tietê, São Vicente, Laranjal Paulista, Sorocaba, Adamantina, São José dos Campos (project run at schools)

Post-processual (postsentencing stage)

Processual (pre-sentencing stage)

\section{Court (judicial competence)}

Criminal proceedings stage

Municipalities of Ponta Processual (pre-senGrossa and Londrina tencing stage 
RIO GRANDE DO SUL

$3^{\text {a }}$ Vara do Juizado
Regional da Infância e
da Juventude/Pro-
grama Justiça Restau-
rativa para o Século
2 I/CEJUSC de Pelotas/
CEJUSC de Santa
Maria/CEJUSC de
Sapiranga

In the capital city of

Porto Alegre: Juizados da Infância e Juventude (youth offending)/Vara de Execuções Criminais - Presídio Central (adult prison)/Vara de Execução de Penas e Medidas Alternativas (court overseeing alternative punishments - such as community service - of adults already sentenced by a criminal court)/Juizado de Violência Doméstica e Familiar contra a Mulher (domestic violence). In the countryside: Vara de Execuções Criminais de Caxias do Sul (courts overseeing alternative punishment of adults alreday sentenced by a criminal court)/Juizado de Violência Doméstica e Familiar contra a Mulher de Novo Hamburgo (domestic violence)/Juizado da Infância e da Juventude de Passo Fundo (youth offending)/Juizado da Infância e da Juventude de Lajeado (youth offending)/Juizado Especial Criminal de Guaiba (low-level crimes)

SANTA CATARINA Coordenadoria Estad- Vara da Infância e ual da Infância e da Juventude/Núcleo de Juventude (youth offending)

Processual (pre-sentencing stage

Processual (pre-sentencing stage

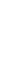

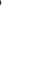

